\section{Frekkhet fører til feil}

\author{
24 behandlingsteam i nyfødtinten- \\ sivmedisin deltok i simuleringstre- \\ ning der oppgaven var å behandle \\ et kritisk sykt spedbarn. Det de \\ ikke visste, var at de også deltok \\ i en studie om betydningen av \\ frekkhet.
}

I en randomisert, blindet studie ble halvparten av teamene utsatt for lett frekke kommentarer før simuleringstreningen startet, mens den andre halvparten fikk nøytrale kommentarer. Kommentarene kom fra en ekstern observatør og var av typen «Jeg er ikke så imponert over det jeg har sett på sykehuset deres så langt». Simuleringen ble filmet, og tre uavhengige eksperter, blindet for eksponeringen, ga teamene poeng for ytelse, deling av informasjon og hjelpsøking.

Teamene som hadde vært utsatt for frekkhet, gjorde det dårligere i simuleringssituasjonen, det gjaldt både diagnostisering og medisinske prosedyrer. Forskjellene skyldtes spesielt mindre informasjonsdeling og at man unnlot å søke hjelp.

- Frekkhet og uhøflighet er noe vi møter en del av i hverdagen, spesielt i stressende situasjoner, sier Corinna Maintz, som er spesialist $\mathrm{i}$ anestesiologi og seksjonsoverlege ved Sykehuset i Østfold, Kalnes.

- Det er allment kjent at dårlig oppførsel ikke bedrer ytelsen i akuttsituasjoner. Deltakerne i denne studien ble kun utsatt for kortvarig uhøflig oppførsel fra en autoritetsperson utenfor selve simuleringsscenarioet, og de frekke kommentarene var ikke spesielt rettet mot enkeltpersoner.

Det spennende med denne studien er at til og med en liten provokasjon har negativ effekt på ytelsen i en simulert akuttsituasjon. Dette viser hvor sterkt vi bør hegne om høflighet og vennlighet i klinisk virksomhet, sier Mainz.

- Bruken av simulering er særlig interessant, og jeg gleder meg til å se simulering utviklet videre som forskningsmetode, sier hun til slutt.

\section{Martine Rostadmo}

Tidsskriftet

\section{Litteratur}

1. Riskin A, Erez A, Foulk TA et al. The impact of rudeness on medical team performance: A randomized trial. Pediatrics 2015; 36: 487-95.

\title{
For mange dødfødsler
}

Antall dødfødsler i verden har gått ned de siste 15 årene, men det er fortsatt store geografiske forskjeller.

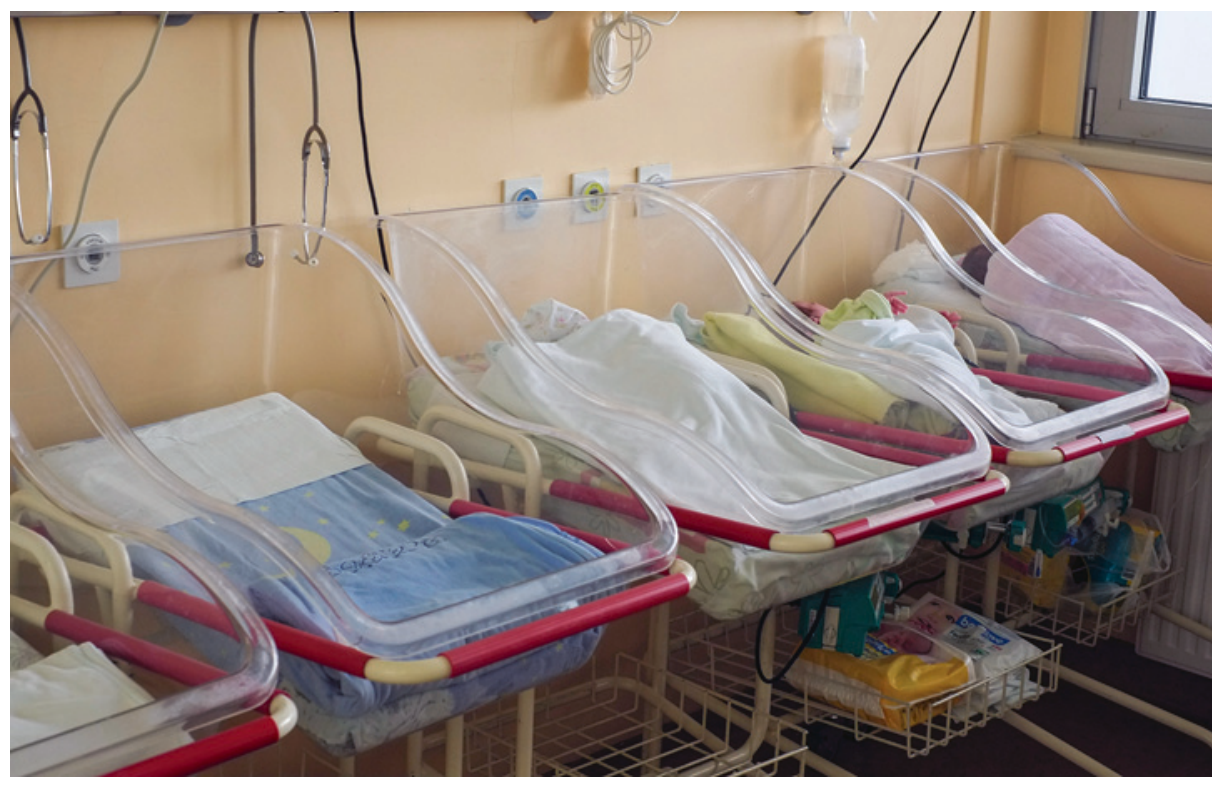

Illustrasjonsfoto: Corbis/NTB scanpix

I en systematisk analyse av dødfødselsrater fra 157 land er utviklingen i og fordelingen av dødfødsler mellom regioner undersøkt (1). En dødfødsel ble definert som en fødsel etter minst 28 ukers svangerskap der barnet ikke viste noen tegn til liv ved fødselen.

Den globale forekomsten av dødfødsler i 2015 var på 18,4 per 1000 fødsler, noe som er en nedgang på rundt $25 \%$ siden 2000 . Det var svært store forskjeller mellom ulike regioner, idet nesten åtte av ti dødfødsler skjer i Sør-Asia og i Afrika sør for Sahara. I seks vesteuropeiske land ble det estimert at man kom til å nå en forekomst på < 2 dødfødsler per 1000 fødsler i 2015, mens Pakistan og 13 afrikanske land $s ø r$ for Sahara hadde en estimert forekomst på > 30 dødfødsler per 1000 fødsler. I de samme landene har det vært en minimal endring i dødfødselsratene de siste 15 årene.
Den globale nedgangen i dødfødsler har gått saktere enn tilsvarende nedgang i mødreog barnedødelighet. Landene med høyest forekomst av dødfødsler som kunne vært unngått ved bedre fødselsomsorg, er de landene der kvaliteten på dødfødselsregistreringen er dårligst. Innsatsen for å bedre fødselsomsorgen i lavinntektslandene i Asia og Afrika må bli bedre for at man skal kunne forebygge dødfødsler.

\section{Matilde Risopatron Berg}

Holter legekontor, Nannestad

\section{Litteratur}

. Blencowe H, Cousens S, Jassir FB et al. National, regional, and worldwide estimates of stillbirth rates in 2015, with trends from 2000: a systematic analysis. Lancet Glob Health 2016; 4: e98-108. 